\title{
The Price of Federal Aid: A Theoretical and Empirical Inquiry ${ }^{\top}$
}

\author{
Paul Kochanowski*
}

\section{Introduction}

The tax burden-grant received ratio is the Federal tax "price" a state pays per dollar of Federal grant funds it receives. In fiscal 1972, this "price" ranged from a low of $\$ 0.34$ for Alaska to a high of $\$ 1.58$ for Connecticut. Table I contains the tax burden-grant received ratios for fiscal 1972. This paper formulates a theoretical model of this ratio; estimates the parameters of this model using cross-sectional state data; and demonstrates the policy implications of the empirical results through a case study. Several important reasons exist for analyzing the determinants of this ratio. First, this ratio is the only valid measure we have of the distributional impact of Federal grant programs because it measures the distribution of grants vis-a-vis the distribution cf tax payments into grant programs. ${ }^{2} \mathrm{Im}-$ mediately, the question comes to mind as to just how much of the difference among states on this ratio can be explained by factors (i.e. income, unemployment, etc.) that would lead to income transfers from some states to others. Second, the ratio is in wide use by state and local government officials both as a simple measure of a state's success or failure in the Federal funds area and as a starting point for discussions related to a state's Federal grant policies. Third,

\section{TABLE I}

Federal Grants-in-Aid to State and Local Governments and Estımated rax Burden of Federal Grants Fiscal Year, 1972

$\begin{array}{lrrr}\text { State } & \begin{array}{c}\text { Grants } \\ \text { (millions) }\end{array} & \begin{array}{c}\text { Estimated tax } \\ \text { Total }\end{array} & \begin{array}{c}\text { Tax burden } \\ \text { per dollar } \\ \text { for aid }\end{array} \\ \text { Alabama } & \$ 35,040.4 & \$ 35,040.4 & \$ 1.00 \\ \text { Alaska } & 671.8 & 399.5 & .59 \\ \text { Arizona } & 176.4 & 59.6 & .34 \\ \text { Arkansas } & 290.6 & 294.3 & 1.01 \\ \text { California } & 393.6 & 220.8 & .56 \\ \text { Colorado } & 4,079.0 & 3,875.5 & .95 \\ \text { Connecticut } & 427.9 & 374.9 & .88 \\ \text { Delaware } & 446.7 & 707.8 & 1.58 \\ \text { Florida } & 96.2 & 122.6 & 1.27 \\ \text { Georgia } & 829.9 & 1,170.3 & 1.41 \\ & 838.0 & 651.8 & .78\end{array}$

*Indiana University at South Bend. 
TABLE I (Con't.)

Federal Grants-in-Aid to State and Local Governments and Estimated Tax Burden of Federal Grants Fiscal Year, 1972

\begin{tabular}{lr} 
State & \multicolumn{1}{c}{ Grants } \\
(millions) \\
Hawaii & 163.4 \\
Idaho & 133.1 \\
Illinois & $1,760.1$ \\
Indiana & 544.6 \\
Iowa & 324.9 \\
Kansas & 297.6 \\
Kentucky & 595.1 \\
Louisiana & 726.3 \\
Maine & 191.3 \\
Maryland & 547.4 \\
Massachusetts & $1,101.1$ \\
Michigan & $1,338.8$ \\
Minnesota & 636.5 \\
Mississippi & 575.4 \\
Missouri & 716.8 \\
Montana & 176.7 \\
Nebraska & 203.7 \\
Nevada & 93.7 \\
New Hampshire & 94.6 \\
New Jersey & $1,040.7$ \\
New Mexico & 281.2 \\
New York & $4,402.9$ \\
North Carolina & 735.8 \\
North Dakota & 126.5 \\
Ohio & $1,208.1$ \\
Oklahoma & 499.9 \\
Oregon & 385.9 \\
Pennsylvania & $1,620.9$ \\
Rhode Island & 178.3 \\
South Carolina & 407.4 \\
South Dakota & 131.8 \\
Tennessee & 688.5 \\
Texas & $1,646.9$ \\
Utah & 216.4 \\
Vermont & 108.4 \\
Virginia & 622.7 \\
Washington & 624.8 \\
West Virginia & 448.0 \\
Wisconsin & 524.8 \\
Wyoming & 105.8 \\
Dist. of Columbia & 563.7
\end{tabular}

\author{
Estimated tax \\ burden of grants ${ }^{\mathrm{a}}$
}

150.7

94.6

$2,274.1$

841.0

420.5

357.4

410.0

459.0

133.2

767.4

$1,110.8$

$1,611.9$

602.7

220.8

753.4

101.6

234.8

108.6

126.1

$1,534.8$

133.2

$3,819.4$

676.3

80.6

$1,867.7$

357.4

343.4

2,067.4

164.7

308.4

80.6

529.1

1,727.5

143.7

66.6

746.4

571.2

231.3

704.3

56.1

175.2
Tax burden per dollar for aid

.92
.71
1.29
1.54
1.29
1.20
.69
.63
.70
1.40
1.01
1.20
.95
.38
1.05
.57
1.15
1.16
1.33
1.47
.47
.87
.92
.64
1.55
.71
.89
1.28
.92
.76
.61
.77
1.05
.66
.61
1.20
.91
.52
1.34
.53
.31

Source: Tax Foundation, Inc., New York, New York

aThe Tax Foundation, Inc., describes the method by which the tax burden for each state is estimated in its monograph, Allocating the Federal Tax Burden by State, 1964. The foundation has developed formulae for allocating on a state by state basis the tax burden for individual income taxes, corporation income taxes, estate and gift taxes, employment taxes and highway trust fund taxes. These estimates provide the information for estimating the tax burdens shown above. Note that the tax burden does not include the cost of "ma"ching funds" the states and localities must provide to obtain certain types of grants. 
because this ratio is a "price" a state pays for its Federal grants, policy questions arise pertaining to what kinds of strategies a state might undertake that will influence this "price" in a favorable direction. As a starting point in these strategy discussions, the basic question that must be answered is whether or not a state has any control over its own ratio, that is, what part of the difference among states on the ratio can be explained by differences in uncontrollable factors such as state characteristics (income, urbanization, etc.) or by factors such as the mix of goods and services a state provides its citizens.

This paper is divided into three sections. Section I develops a model of ratio determination. Section II estimates the parameters of the model formulated in section I and discusses the empirical results. Section III demonstrates the use of the empirical results as a policy tool through application of these results to a case study.

\section{I}

\section{A Simple Model}

If we focus our analysis on any one state, say the ith state, the magnitude of that state's tax burden-grant received ratio depends on two sets of factors, one set of factors that influences that state's ability to obtain Federal grants, some of which are controllable by the ith state, others which are not, and a second set of factors that determines the payment of taxes the ith state contributes into grant-in-aid programs, none of which appear controllable. In a general functional form, we can represent the ith state's ratio, $R_{i}$, as

$$
\text { 1) } \mathrm{R}_{\mathrm{i}}=\mathrm{T}_{\mathrm{i}}\left(\mathrm{Y}_{\mathrm{i}}\right) / \mathrm{G}_{\mathrm{i}}\left(\mathrm{X}_{\mathrm{i}}\right),(\mathrm{i}=1,2,3, \ldots \ldots 50)
$$

The term $\mathrm{G}_{\mathrm{i}}\left(\mathrm{X}_{\mathrm{i}}\right)$ represents the grants the ith state receives during the time period under consideration. We theorize that the level of grant receipts is a function of various characteristics of the ith state which are represented by the vector $\mathrm{X}_{i}$. Similarly, the term $\mathrm{T}_{\mathrm{i}}\left(\mathrm{Y}_{\mathrm{i}}\right)$ represents the ith state's tax payments into Federal aid programs, the level of which is also a function of certain characteristics of the ith state as given by the vector $\mathrm{Y}_{\mathrm{i}}$. Individual elements of $\mathrm{X}_{i}$ and $\mathrm{Y}_{\mathrm{i}}$ increase (decrease) $\mathrm{R}_{\mathrm{i}}$ if they decrease (increase) state i's ability to obtain grants, $\mathrm{G}_{\mathrm{i}}$, or if they raise (lower) the amount of taxes, $\mathrm{T}_{\mathrm{i}}$, it pays into Federal aid programs. In the remainder of this section, we discuss state characteristics as they affect, $\mathrm{G}_{\mathrm{i}}, \mathrm{T}_{\mathrm{i}}$, and $\mathrm{R}_{\mathrm{i}}$.

State Characteristics Influencing the Level of $R_{\mathrm{i}}$ Through Both $G_{\mathrm{i}}$ and $T_{\mathrm{i}}$

Per Capita Income (I): The level of state i's per capita income is a state characteristic that enters into the determination of both grant receipts and tax burden." A substantial portion of Federal aid programs is redistributional in nature. States possessing relatively low per capita income, some Southern states for instance, would by the redistributional nature of certain grant programs be eligible to receive relatively more dollars than other more prosperous states. This 
effect indicates that $\partial \mathrm{G}_{\mathrm{i}}\left(\mathrm{X}_{\mathrm{i}}\right) / \partial \mathrm{I}_{\mathrm{i}}<0$. But per capita income also determines to a great extent the level of $\mathrm{T}_{i}$. Given the slightly progressive nature of the tax system we have in the United States, lower per capita income states would contribute relatively smaller amounts of taxes into grant programs than their more prosperous counterparts indicating that $\partial \mathrm{T}_{\mathrm{i}}\left(\mathrm{Y}_{\mathrm{i}}\right) / \partial \mathrm{I}_{\mathrm{i}}>0$. Thus the income effect on $\mathrm{G}_{i}$ and on $\mathrm{T}_{i}$ reinforce each other or more precisely

$$
\begin{aligned}
& \partial \mathrm{R}_{\mathrm{i}} / \partial \mathrm{I}_{\mathrm{i}}=\left(\partial \mathrm{T}_{\mathrm{i}} / \partial \mathrm{I}_{\mathrm{i}} \cdot \mathrm{G}_{\mathrm{i}}\left(\mathrm{X}_{\mathrm{i}}\right)-\right. \\
& \left.\partial \mathrm{G}_{\mathrm{i}} / \partial \mathrm{I}_{\mathrm{i}} \cdot \mathrm{T}\left(\mathrm{Y}_{\mathrm{i}}\right)\right) /\left(\mathrm{G}_{\mathrm{i}}\left(\mathrm{X}_{\mathrm{i}}\right)\right)^{2}>0
\end{aligned}
$$

Urbanization (URB) The impact of urbanization on $\mathrm{R}_{\mathrm{i}}$ is transmitted through several variables and hence also influences both grant receipts, $\mathrm{G}_{\mathrm{i}}$, and tax payments, $\mathrm{T} .{ }^{4}$ If we consider first the impact of urbanization on $\mathrm{G}_{\mathrm{i}}$, there appear to be two reasons why greater urbanization may lead to relatively higher levels of $G_{i}$ and thereby to lower $R_{i}$. The first of these reasons we call the visibility factor. Many of the Federal grant programs are intended to alleviate problems most visible and in some cases, most pronounced in urban areas. Examples of these problems are urban decay, slum housing, crime, health, discrimination and urban poverty. Visibility and the occurrence of these problems in highly urbanized areas would suggest that states having large urban concentrations would have an advantage in obtaining grants to study and solve these social and economic ills.

The second reason grants may be positively influenced by greater urbanization we term the conservatism factor. For a long time it has been thought that rural, less urbanized areas in the United States tend to be relatively conservative in their political views. If this conservatism permeates the philosophy these areas have towards using Federal funds, then it is highly conceivable that less urbanized states would voluntarily participate in Federal grant programs to a lesser extent. Here again, we have another reason to suspect that urbanization and grant receipts are positively related.

A state's ratio is determined, however, not only by its grant receipts but, as noted previously also by its tax payments into grant programs. All of the evidence suggest that urbanization and per capita real income are positively related. In that case, highly urbanized areas would have per capita tax contributions into Federal programs exceeding those of less urbanized, rural areas. The tax effect of urbanization on the ratio would be in the opposite direction of the grant effect discussed above. The net impact of the two forces depends then on which, if either, is the strongest - a factor we have not yet determined. We cannot, therefore, make any prior statements about the sign of $\partial R_{i} / \partial U_{R B}$ since it depends on whether $\partial \mathrm{G}_{\mathrm{i}}\left(\mathrm{X}_{\mathrm{i}}\right) / \partial \mathrm{URB}_{\mathrm{i}}$ is larger or smaller than $\partial \mathrm{T}_{\mathrm{i}}$ $\left(\mathrm{Y}_{\mathrm{i}}\right) / \partial \mathrm{URB}_{\mathrm{i}}$ in the expression

$$
\begin{gathered}
\partial R_{i} / \partial \operatorname{URB}_{\mathrm{i}}=\left(\partial \mathrm{T}_{\mathrm{i}}\left(\mathrm{Y}_{\mathrm{i}}\right) / \partial \operatorname{URB}_{\mathrm{i}} \cdot \mathrm{G}_{\mathrm{i}}\left(\mathrm{X}_{\mathrm{i}}\right)-\right. \\
\left.\partial \mathrm{G}_{\mathrm{i}}\left(\mathrm{X}_{\mathrm{i}}\right) / \partial \mathrm{URB}_{\mathrm{i}} \cdot \mathrm{T}_{\mathrm{i}}\left(\mathrm{Y}_{\mathrm{i}}\right)\right) /\left(\mathrm{G}_{\mathrm{i}}\left(\mathrm{X}_{\mathrm{i}}\right)\right)^{2}
\end{gathered}
$$


Variables Influencing the Level of $R_{\mathrm{i}}$ through $G_{\mathrm{i}}$

Unemployment Rates (UN). Differential state unemployment rates influence the level of $R_{i}$ through their effect on a state's ability to obtain certain types of funding. ${ }^{6}$ Funds earmarked for distressed areas or states under the Emergency Unemployment Act of 1971 use unemployment rates for formula allocation. If state $\mathrm{i}$ has a relatively high unemployment rate, for example, its ability to obtain certain types of funding would increase thereby suggesting that $\partial \mathrm{R}_{\mathrm{i}} / \partial \mathrm{UN}_{\mathrm{i}}<0$.

The Mix of State Financed Expenditure $\left(E_{\mathrm{j}}\right)$ : As far as I can ascertain from review of the literature, no attention has been given to the influence the mix of goods and services a state provides may have on the amount of funding it obtains from the Federal government. Yet there is good reason to argue that this mix of goods and services may have a significant effect on $\mathrm{R}$. The largest single category of Federal aid in 1974 is the welfare area. For the most part, these grants require participation by the states in terms of their own expenditures. States choosing to spend relatively large amounts on welfare expenditures would undoubtedly be able to make greater use of these welfare oriented federal programs than states choosing to spend less. To the extent that other types of federal aid are a function of a state's own matching funds, similar analysis would apply to these other aid categories. If a state's mix of expenditures does influence the level of federal aid in various categories that it receives, then

$\partial R_{i} / \partial E_{j i}<0$ where $E_{j i}$ is the jth type of federally-aided expenditure from the ith state's own funds. Note also that if this relationship does hold it may be possible to some extent for a state to influence the level of its $R$ through adjustment of its composition of state funded goods.

\section{Political Variables Influencing Grant Receipts, $G_{\mathrm{i}}$}

If we asked a political scientist friend what he thought of the tax burdengrant received model we have developed thus far, he would certainly chide us for the lack of attention given political factors that might influence a state's grant receipts. He might argue that political leaders will derive advantage in rewarding those whose past and present support has resulted in their positions of political power. Or, as Ferman notes in his study of grant-in-aid distribution:

Thus it is expected that states supporting (or rewarding) the national administration will be rewarded (or supported) by that administration more than non-supporting states, ergo the former will be allocated more per capita grants-in-aid than the latter.

However, the suggested relationship between political factors - at least those which we are at present able to quantify at the state level - has not been verified through empirical work. Table 2 contains Ferman's results showing the impact of certain political variables on grant-in-aid distribution.

Based on these results he concludes:

It is evident that none of the indicators are systematically related to the dependent variable - the simple correlations are insignificant (with one 
exception) and there is no consistency in direction. Thus, it appears reasonable to conclude that the research representation of political association/support variables is not related to the distribution of grants-in-aid, i.e., grants-in-aid are not distributed in a way rewarding states associated with the national administration by political party or voting record.

Further, the results did not change when area, population and population density were separately controlled. And while our political scientist friend may not agree with us, we have opted, based on the above results, to exclude political association/support variables from our model determining $R_{i}$, these variables having negligible explanatory power.

\section{TABLE II}

Political Variables and Grants-in-Aid ${ }^{1}$

\begin{tabular}{|c|c|c|c|c|}
\hline \multirow[t]{2}{*}{ Variable } & \multirow[t]{2}{*}{ Independent Variables } & \multicolumn{3}{|c|}{$\begin{array}{c}\text { Dependent Variables } \\
\text { Per Capita } \\
\text { Grants-in-aid (x) }\end{array}$} \\
\hline & & 1955 & 1959 & 1963 \\
\hline $\mathrm{A}$ & Senators Associated with & & & \\
\hline & Presidential Party by States & -.31 & -.18 & .24 \\
\hline B & Governor and Presidential Party & & & \\
\hline & Congruence & .11 & .28 & -.04 \\
\hline & $\begin{array}{l}\text { Percentage State Congressmen Affiliated } \\
\text { with Presidential Party by State }\end{array}$ & -.06 & -.06 & .06 \\
\hline $\mathrm{D}$ & Percentage State Vote for Successful & & & \\
\hline & Presidential Candidate & .08 & .04 & -.15 \\
\hline $\mathrm{E}$ & $\begin{array}{l}\text { Percentage Rank of State Vote for } \\
\text { Successful Presidential Candidate } \\
\mathrm{r}=.285 \text { required for } \mathrm{p}=.05\end{array}$ & -.06 & .07 & -.26 \\
\hline
\end{tabular}

1The distributions are primarily from: Statistical Abstracts of the United States, and Tax Foundation, Inc., Facts and Figures on Government Finance. For complete citation see G. Ferman, "Effect of Select System Characteristics on Inter-Level Bargaining: Particular Emphasis on Federalism and the Distribution of Public Monies" (unpublished dissertation, University of Pennsylvania, 1969), 73-76, 80, 148-49: When the same distribution appears again in another table, the source will not be repeated in the latter table's footnote.

Source: G. Ferman, Output Analysis: "The Distribution of Grants-in-Aid 1957-1967, A Preliminary Analysis, working paper No. 10 Center for the Study of Federalism, Temple University.

\section{Statistical Results}

\section{II}

A linear form of the model described above is given as

2) $\mathrm{R}_{\mathrm{i}}=\mathrm{a}_{\mathrm{o}}+\mathrm{a}_{1} \mathrm{I}_{\mathrm{i}}+\mathrm{a}_{2} \mathrm{URB}_{1 \mathrm{i}}+\mathrm{a}_{3} \mathrm{URB}_{2 \mathrm{i}}+\mathrm{a}_{4} \mathrm{UN}_{\mathrm{i}}+\mathrm{a}_{5} \mathrm{E}_{\mathrm{ei}}+$

$$
\mathrm{a}_{6} \mathrm{E}_{\mathrm{wi}}+\mathrm{a}_{7} \mathrm{E}_{\mathrm{hi}}+\mathrm{a}_{8} \mathrm{E}_{\text {hyi }}+\mathrm{a}_{9} \mathrm{E}_{\text {nri }}+\mathrm{a}_{10} \mathrm{E}_{\text {pri }}+\mathrm{a}_{11} \mathrm{P}_{\mathrm{i}}+\mathrm{U}_{\mathrm{i}}
$$

where the variables are defined as follows: 
$R_{\mathrm{i}}=$ the ith state's tax burden-grant received ratio

$\mathrm{I}_{\mathrm{i}}=$ per capita income of the ith state

$\mathrm{URB}_{1 \mathrm{i}}=$ the percentage of the ith state's population that is urbanized

$\mathrm{URB}_{2 \mathrm{i}}=$ the number of SMSAS in the ith state having populations of 1 million or more

$\mathrm{UN}_{\mathrm{i}}=$ the average annual unemployment rate of the ith state

$\mathrm{E}_{\mathrm{ei}}=$ per capita education expenditures of the ith state from its own funds

$\mathrm{E}_{\mathrm{wi}}=$ per capita welfare expenditures of the ith state from its own funds

$\mathrm{E}_{\mathrm{hi}}=$ per capita health expenditures of the ith state from its own funds

$\mathrm{E}_{\text {hyi }}=$ per capita highway expenditures of the ith state from its own funds

$\mathrm{E}_{\mathrm{nri}}=$ per capita natural resource expenditures of the ith state from its own funds

$\mathrm{E}_{\mathrm{pri}}=$ per capita prison expenditures of the ith state from its own funds

$\mathrm{P}_{\mathrm{i}}=$ population of the ith state

$\mathrm{U}_{\mathrm{i}}=$ that part of $\mathrm{R}_{\mathrm{i}}$ not explained by the set of regressors

$\mathrm{a}_{\mathrm{o}}$ through $\mathrm{a}_{11}=$ coefficients obtained from the regression analysis The parameters of equation (2) were estimated from data for the fifty states covering the years 1970 and 1971 and are given as

$\left.2^{\prime}\right)$

$$
\begin{aligned}
& \mathrm{R}_{\mathrm{i}}=-.7134+.00062 \mathrm{I}_{\mathrm{i}}-.00064 \mathrm{URB}_{1 \mathrm{i}}+.07545 \mathrm{URB}_{2 \mathrm{i}}-.000289 \mathrm{UN}_{\mathrm{i}} \\
& -.00094 \mathrm{E}_{\mathrm{ei}}-.00811 \mathrm{E}_{\mathrm{wi}}+.00521 \mathrm{E}_{\mathrm{hi}}+.00219 \mathrm{E}_{\mathrm{hyi}} \\
& -.02034 \mathrm{E}_{\text {nri }}-.00463 \mathrm{E}_{\text {pri }} \\
& \mathrm{R}^{2}=.8070 ; \mathrm{F}=14.45 \mathrm{SEE}=.177 ;()=\mathrm{T} \text { value }
\end{aligned}
$$

As a group the explanatory variables explain about $81 \%$ of the variation in $R_{i}$ and the $\mathrm{F}$ value allows us to reject at the .01 level the hypothesis that the entire vector of coefficients is equal to zero. State per capita income $\left(I_{i}\right)$, state financed per capita welfare expenditures $\mathrm{E}_{\mathrm{wi}}$, per capita education expenditures $\mathrm{E}_{\mathrm{ei}}$ and per capita natural resource expenditures $\mathrm{E}_{\mathrm{nri}}$ are all statistically significant and have the direction of effect suggested by our previous discussion. While it might at first appear that we can conclude that urbanization has a neutral effect on $R_{i}$, since neither urbanization variable is significant, intercorrelation between the urbanization variables and other regressors makes this conclusion somewhat tenuous. The low t values on $\mathrm{URB}_{2 \mathrm{i}}$ and $\mathrm{URB}_{2 \mathbf{i}}$, rather than indi- 
cating that these variables have a negligible impact on $\mathrm{R}$, are instead the result of high standard errors resulting from the presence of multicollinearity. ${ }^{9}$

\section{An Attempt to Isolate the Effect of Urbanization by Eliminating Multicollinearity}

If we are to isolate the effect of the urbanization variable, we must in some way reduce or eliminate the effects of intercorrelation between that variable and other independent variables; more specifically, the intercorrelation between urbanization, income, and welfare expenditures. The technique we follow is based on the work of Ridker and Henning. ${ }^{10}$ This procedure relies on two properties of least squares estimation methods: first, that calculated residuals from a least squares regression equation are orthogonal to the explanatory variables of that equation and second, that the inclusion of a regressor that is orthogonal to previously included regressors will not bias their estimated coefficients. As an example of this technique, assume that we are regressing $\mathrm{Z}$ against two regressors $\mathrm{X}$ and $\mathrm{Y}$. Further assume that $\mathrm{X}$ and $\mathrm{Y}$ are highly intercorrelated. Under these circumstances the two regressors might explain a large amount of the variation in $\mathrm{Z}$ and yet at the same time - because of multicollinearity - both have $t$ values less than the level required to reject the hypothesis that their regression coefficients are not equal to zero. One solution to this problem is suggested by Ridker and Henning.

A reasonable resolution of this problem is to replace $\mathrm{X}$ with another variable RX, that is orthogonal to $\mathrm{Y}$... This new variable is obtained by subtracting from the actual values of $\mathrm{X}$ the computed values obtained from an auxiliary regression $\mathrm{X}$ against $\mathrm{Y}$. RX, in other words, is actual $\mathrm{X}$ "corrected for" $\mathrm{Y}$. The observations on RX are, of course, simply the residuals from this auxiliary regression, and the adjustment may therefore be referred to as "residualization". The effect of this adjustment is to attribute to $\mathrm{Y}$ whatever covariation exists between it and $\mathrm{X}$. The coefficient of $\mathrm{Y}$ is the same as it would have been had $\mathrm{X}$ not been included. The coefficients of all other variables, including that for RX, are unaffected by this procedure.

Based on this technique and in an attempt to isolate the effect of urbanization on the ratio, two auxiliary relationships were run:

$$
\begin{aligned}
& \mathrm{I}_{\mathrm{i}}=2003.12+\underset{(5.04)}{25.05 \mathrm{URB}_{1 \mathrm{i}}} \\
& \mathrm{E}_{\mathrm{wi}}=-8.78+.497 \mathrm{URB}_{1 \mathrm{i}}
\end{aligned}
$$

The residuals of these two regressions $R I_{i}$ and $R E_{w i}$ were used in place of $I_{i}$ and $E_{w i}$. The effect of this operation is to pull into the urbanization variable the influence urbanization has on both the income and welfare regressors. Fur- 
ther, because of high intercorrelation between the two urbanization variables and the urbanization and population variables $\mathrm{URB}_{\mathrm{a}}$ and $\mathrm{P}_{\mathrm{i}}$ were dropped as regressors. Equation (2) after adjustments for multicollinearity is given as:

$$
\begin{gathered}
\left.2^{\prime \prime}\right) \quad \mathrm{R}_{\mathrm{i}}=.3639+.00056 \mathrm{RI} \mathrm{i}+.01425 \mathrm{URB}_{1 \mathrm{i}}-.00258 \mathrm{UN}_{\mathrm{i}} \\
\\
-.00172 \mathrm{E}_{\mathrm{ei}}-.01112 \mathrm{RW}_{\mathrm{i}}+.00556 \mathrm{E}_{\mathrm{hi}}+.00282 \mathrm{E}_{\mathrm{hyi}} \\
(2.61) \quad(3.99) \\
-.01621 \mathrm{E}_{\mathrm{nri}}-.00058 \mathrm{E}_{\mathrm{pri}} \\
(3.64) \quad(.056) \\
\mathrm{R}^{2}=.8049 ; \mathrm{F}=18.34 ; \mathrm{SEE}=.174 ; \quad(\quad)=\mathrm{t} \text { value }
\end{gathered}
$$

As in equation $\left(2^{\prime}\right)$, the per capita income, education expenditures, welfare expenditures and natural resource expenditure regressors are significant at the .01 level and have the predicted sign. But in addition, the urbanization variable is also significant. Its sign indicates that the tax effect of urbanization swamps the grant effect. This in turn implies that there is a redistribution of grant monies from more to less urbanized areas (about $\$ 0.14$ for each increase of $10 \%$ in the percentage of a state's population which is urbanized). In a sense, this is what we should expect. We probably tend to think of large urban concentrations as placed where huge sums of federal funds are spent on welfare, urban renewal, crime, etc. When we consider federal grant distribution, this is actually the case (see Table I), but the tax impact of urbanization is often forgotten about. Per capita money income in highly urbanized areas is substantially above that of other more rural places. States having large urban concentrations pay, on a per capital basis, relatively more into Federal grant programs. Our results show that these higher tax payments more than offset the increased grant receipts these agglomerations are able to obtain. ${ }^{11}$

\section{The Importance of Individual Regressors}

The importance of individual regressors in explaining the variation in $R$ cannot be directly determined by reference to the regression coefficients obtained - their magnitude being dependent on the unit of measure used for each regressor. To overcome this unit of measurement problem, we rely on a transformation of the original regression coefficients into what has come to be called "beta coefficients." The transformation is straightforward. Each regression coefficient is multiplied by the ratio of its standard deviation to the standard deviation of the dependent variable $R$. These new coefficients are then standardized so that the sum of their absolute values adds up to 100. They indicate approximately the relative importance of different variables in terms of their contributions to the variation in the regression. ${ }^{12}$ The results of this operation are presented in Table III.

As can be seen in this table, the single most important factor explaining variation in the price states pay for Federal aid is the residualized income vari- 


\section{TABLE III}

Beta Coefficients for Individual Regressors

Beta

Regressor

Coefficien

RI

24.16

URB

21.56

UN

$-\quad .40$

$\mathrm{E}$

RW

$-10.03$

Regressor
$\mathrm{E}_{\mathrm{h}}$
$\mathrm{E}_{\mathrm{hy}}$
$\mathrm{E}_{\mathrm{nr}}$
$\mathrm{E}_{\mathrm{pr}}$

Beta

Coefficient

7.81

5.20

$-15.24$

able. Combining the urbanization and the income variables accounts for about $50 \%$ of the explained variance in $\mathrm{R}$. Another $40 \%$ of the explained variation in $R_{i}$ is accountable by the per capital level of three state financed expenditures - education expenditures, residualized welfare expenditures and natural resource expenditures. If we take as given the fact that the level and mix of expenditures a state provides from its own revenue sources is a controllable factor to the state, then this evidence suggests that a sizeable portion (about onehalf) of the explained variation in $R_{i}$ is simply accounted for by differences in preferences by states with regards to levels and mixes of state financed expenditures. More concretely, given that about $80 \%$ of all Federal grants require matching by the receiving government, the high price some states pay for the Federal aid they receive may reflect a state financed mix and/or level of goods and services skewed towards expenditures which do not qualify the state for large amounts of Federal funds. We shall study this question in more detail in the next section when we consider, inter alia, the impact a state's expenditure mix has on the price of it's Federal aid vis-a-vis other states.

\section{III}

\section{Policy Implications}

The policy implications of the statistical work presented thus far can best be demonstrated by an actual case where these results were used to answer questions and suggest further lines of research related to a state's future grantin-aid strategy. Indiana for many years had ranked near or at the top on the tax burden-grant received ratio. In 1972, with a change in the political administration of the state, evidence of concern over the state's relatively poor showing in the federal funds area became very apparent. The concern was not only due to Indiana's poor showing on the ratio but also came about because the state found itself in a very tight fiscal position, forcing more and more politicians to question whether or not increased federal funds utilization might not be a remedy for a tax structure which had not been changed in the previous eight years.

Immediately a three sided controversy broke out. On one side of the controversy were those, who had no opposition to increased use of federal monies 
per se, but who argued that the ratio and the distribution of federal grants were simply a matter of formula allocation. Indiana might not like its position relative to other states but no action on its part would have any effect on changing this. On another side of the controversy were those who took the position that Indiana could, if it tried, improve its relative position on the ratio, but that this was not all together desirable. These arguments took two different lines of attack. One contigent of those arguing on this side saw Indiana's ratio being the direct result of Indiana's citizens demanding at the state level a mix of goods that simply did not allow much use of federal funds. Along these lines this contingent pointed to the large amounts of federal monies in the area of welfare and to the fact that Indiana desired to present a bundle of goods and services containing relatively low levels of state financed welfare expenditures thereby limiting Indiana's ability to obtain Federal grants. The other contingent took a much stronger stand against federal grant usage. Their position was that Indiana's low grant receipts came about because of a voluntary unwillingness to participate in federal programs. In simple terms, Federal programs had high costs associated with their use and Indiana's avoidance of them was both a rational and wise decision that should not be changed. Finally, a third side of the controversy presented the position that Indiana not only should increase its use of Federal funds but that its poor performance was due to its lack of grantsmanship and its lack of a centrally coordinated effort at the state level, this effort being needed to keep abreast of changes in the rules of the dynamic federal funds game. ${ }^{13}$

The results given in equation $\left(2^{\prime \prime}\right)$ were used to answer some of the questions brought forth by this controversy. More specifically, three questions were considered: first, was Indiana's ratio position relative to other states primarily a matter of formula allocation? Second, was Indiana's ratio position relative to other states primarily the result of Indiana's mix of goods and services? And third, what part of the difference between Indiana and other states on the ratio was explainable by both factors that affect formula allocation and by Indiana's goods and service mix? It was considered imperative to provide answers to these questions before considering other facets of the controversy simply because these answers provided information on whether or not other facets should be studied. More specifically, if it could be shown that most of the variations amongst states in the ratio were attributable to formula allocation factors or to the mix of goods and services states found desirable to provide, little need would exist for studying the cost and benefits of using federal grants, or various techniques such as grantsmanship and centrally coordinated grant efforts; the outcome of these studies would be of no consequence to a state, its characteristics having predestined it to a relatively high ratio.

To arrive at answers to the three questions, equation (2") was used to compare Indiana with two other groups of states. The first group was comprised of those states receiving back about as much as they had paid into grant programs - their ratios, near 1.0. The other group of states received back substantially more than they had paid into grant programs and had ratios in the range of .50 to .65. Data in Table IV present that comparison. Entries in this table were arrived at by using the coefficients of significant regressors of equation $\left(2^{\prime \prime}\right)$ multi- 
plied times the difference between Indiana and states in the left hand column for each of the significant variables. For example, Indiana had a .12 higher ratio than did California partially because of its greater level of per capita income not explained by urbanization. Indiana per capita income, after eliminating the effects of urbanization, was $\$ 210$ higher than California per capita income. The +.12 entry in the table is the result of multiplying the $\$ 210$ difference by .00056 , the regression coefficient on $\mathrm{I}_{\mathrm{i}}$ in equation $\left(2^{\prime \prime}\right)$.

This comparison method might be criticized on the basis that it implicitly assumes that the partial derivative of the ratio, $R$, with respect to a significant regressor is equal to that regressor's coefficient. In other words, it assumes that a change in the value of a significant regressor does not influence the values taken on by any of the omitted regressors. In the presence of strong multicollinearity this procedure would obviously break down. Consider the simple case where $\mathrm{Z}$ is regressed against $\mathrm{X}$ and $\mathrm{Y}$, where $\mathrm{X}$ and $\mathrm{Y}$ are highly correlated. Then $\mathrm{Z}=\mathrm{a}_{\mathrm{o}}+\mathrm{a}_{1} \mathrm{X}+\mathrm{a}_{2} \mathrm{Y}$ and $\mathrm{dZ} / \mathrm{dX} \neq \mathrm{a}_{1}$ since $\mathrm{dY} / \mathrm{dX} \neq 0$. But the crux of the problem here is the presence of the strong relationship between $\mathrm{X}$ and Y. If that intercorrelation is eliminated, as we have in equation $\left(2^{\prime \prime}\right)$, it appears perfectly justifiable to argue that $\mathrm{dZ} / \mathrm{dX}=\mathrm{a}_{1}$ since the covariance of $R Y$ and $X$ is zero, where $R Y$ is our residualized variable. Note that while $d Z / d X$ $=\mathrm{a}_{1}$, since $\mathrm{dRY} / \mathrm{dX}=0$, the coefficient $\mathrm{a}_{1}$ now captures both the direct impact of $\mathrm{X}$ on $\mathrm{Z}$ and indirect impact of $\mathrm{X}$ on $\mathrm{Z}$ through $\mathrm{X}$ 's influence on $\mathrm{Y}$.

The immediate impression given by the pattern of plus and minus signs in Table IV is that the mix of goods and services, and variables determining formula allocation of grants are a significant factor accounting for Indiana's position relative to the comparison states. For three of the comparison categories per capita income, per capita welfare expenditures and per capita natural resource expenditures - fifty-four of the fifty-seven entries have plus signs. As noted in the table, a plus sign indicates that Indiana's value on a characteristic relative to the comparison state causes Indiana's ratio to be higher. Further, the values in the welfare category for those states having ratios between .95 and 1.05 are in most instances large in contrast to entries given in the other categories. And as those anxious to support the mix of goods theory of ratio determination would be quick to point out, this simply reflects the desire by the state of Indiana to provide state financed welfare payments at a much lower level than many of the comparison states. As a point of fact, in 1973 only South Carolina had lower state financed per capita welfare expenditures than did Indiana.

But the pattern of signs is only a partial answer to the questions presented above. Certainly the pattern does point to the fact that certain characteristics of Indiana cause its ratio to be higher than the comparison states. What it does not tell us, however, is just what part of the total difference between Indiana and these comparison states can be explained by this set of regressors. The answer to how important these characteristics are in explaining differences between Indiana and the comparison states is found in Table V. The last entry in this table shows that over the nineteen comparison states the characteristic regressors explain about $60 \%$ of the difference between these states and the state of Indiana. Even 
Comparison of Indiana to Other States - The Influence of Significant Regression

Variables on Tax Burden-Grant Received Ratio

States With Tax Burden-Grant Received Ratios Between .95 and 1.05

State

California

Minnesota

Missouri

New Hampshire

New York

Rhode Island

Texas

Virginia

Washington

Alabama

Arkansas

Kentucky

Louisiana

Montana

North Dakota

Oklahoma

South Dakota

Utah

Vermont

Wyoming

\section{Residualized}

Income

$+.12$

$+.003$

$+.12$

$-.04$

$-.26$

$+.24$

$+.39$

$+.08$

$+.04$
$\%$ Urbanization

$-.37$

-.10
-.07

$+.13$

$-.29$

$-.31$

$-.17$

$+.03$

$-.11$
Residualized

Welfare

$+.40$

$+.04$

$+.12$

$+.12$

$+.34$

$+.38$

$-.01$

$+.02$

$+.26$

Per Capita

Per Capita

Education Exp. Natural Resources

Total

States With Tax Burden-Grant Received Ratios Between .50 and .65

$\begin{array}{ll}+.44 & +.08 \\ +.35 & +.17 \\ +.24 & +.14 \\ +.46 & -.01 \\ +.05 & +.13 \\ +.14 & +.23 \\ +.31 & -.03 \\ +.04 & +.22 \\ +.55 & -.17 \\ -.32 & +.37 \\ +.05 & +.04\end{array}$

$+.19$

$+.14$

$+.21$

$+.17$

$+.20$

$+.21$

$+.29$

$+.20$

$-.03$

$+.03$

$+.26$

$+.10$

$+.10$

$+.10$

$-.11$

$+.02$

$+.06$

$+.06$

$+.19$

$+.38$

$+.15$

$+.22$

$+.20$

$-.16$

$+.34$

$+.17$

$+.16$

$+.46$

+Indicates that Indiana's characteristics relative to state in left hand column resulted in a higher tax burden-grant received ratio.

-Indicates that Indiana's characteristics relative to state in left hand column resulted in a lower tax burden-grant received ratio.

$$
\begin{aligned}
& +.04 \\
& +.08 \\
& +.13 \\
& +.08 \\
& +.28 \\
& +.21 \\
& +.10 \\
& +.23 \\
& +.10 \\
& +.28 \\
& +.49
\end{aligned}
$$

$+.64$

$+.81$

$+.55$

$+.62$

$+.64$

$+1.06$

$+.83$ 


\section{TABLE V}

Comparison of Indiana to Other States - Explained and Unexplained Differences

States With Tax Burden-Grant Received Ratios Between .95 and 1.05

Differences Between

Indiana and Other

$$
\text { States on }
$$

Tax Burden-Grant

State

Received Ratio-1971

\section{Difference Explained \\ in Table IV}

California

Minnesota

Missouri

New Hampshire

Rhode Island

Texas

Virginia

Washington

.66
.66
.57
.57
.62
.58
.57
.59

Alabama

Arkansas

Kentucky

Louisiana

Montana

North Dakota

Oklahoma

South Dakota

Utah

Vermont

Wyoming

.38
.15
.22
.20
.34
.17
.16
.46

\section{Ratio}

Difference
Unexplained

$\%$ Explained

$\begin{array}{ll}58 & 42 \\ 23 & 77 \\ 39 & 61 \\ 35 & 65 \\ 55 & 45 \\ 29 & 71 \\ 28 & 72 \\ 78 & 22\end{array}$

States With Tax Burden-Grant Received Ratios Between .50 and .65

Average over all states above

Average over States Having Ratios $.95-1.05$
Average over States Having Ratios $.50-.65$

$\begin{array}{rrr}1.10 & .76 & .24 \\ 1.07 & .67 & .40 \\ 1.00 & .70 & .30 \\ 1.01 & .69 & .32 \\ 1.08 & .64 & .44 \\ 1.07 & .81 & .16 \\ .96 & .55 & .41 \\ 1.04 & .62 & .42 \\ .98 & .64 & .34 \\ 1.04 & 1.06 & - \\ .96 & .83 & .13\end{array}$

$69-31$

Data used are for fiscal 1971. Indiana's tax ratio in $1971=\$ 1.61$ 
more important is the fact that for the comparison group having ratios .95 to 1.05 only $43 \%$ of the difference between this group and Indiana is explainable by formula and mix of goods factors. And within this group - the comparison to Minnesota - as much as 77\% of the difference cannot be explained by the regressors presented in Table IV.

This data led to the conclusion that while formula factors have some impact on Indiana's relative position; that while mix of goods factor also has some impact on Indiana's relative position, the combined effect of these factors could not explain a large portion of differences between Indiana and the nineteen comparison states. More specifically, after controlling for difference in state characteristics presented in Table IV, Indiana's ratio would have been about 1.25 in contrast to its actual level in 1971 of 1.61 . Assuming tax payments into grant programs to be a non-controllable variable, this would in turn mean that a $\$ 150$ million annual shortfall in grant receipts could not be explained by the set of variables being considered.

This evidence suggested to the State that many of the other facets of the Federal grant controversy should be considered. Along these lines studies were performed to determine the validity of the charges waged against the use of Federal funds. These studies attempted to ascertain the importance of such factors as administrative cost incurred by the state of grant programs, the impact on the composition of state provided goods and services induced by the use of Federal grants, the amount of subsidy involved in various types of grant programs, the potential costs to the state of errors in predicting the length of funding and/or changes in the eligibility requirements for various federal programs. Further, recommendations and studies were made related to the areas of grantsmanship, a central administration source within the state for information on grant programs and methods for reviewing proposals to make use of new sources of Federal funds as well as proposals to increase the state's participation in various Federal grant areas.

\section{Summary}

In summary, the type of evidence presented by equation $\left(2^{\prime \prime}\right)$ is a starting point in any attempt to understand state or regional variations in the tax burdengrant received ratio. Any state interested in determining why it differs from other states or from a whole group of states can at the least determine what part of the difference is explainable by factors it has little control over, such as its level of income and percentage of population urbanized. In addition, that state can determine how the mix of goods and services it provides affects its ratio in relationship to other states having a somewhat different mix. Finally - although admittedly only as a by-product - the analysis yields some answers on just how important such things as grantsmanship or a centrally coordinated effort are to explaining differences in the ratio between states and regions.

\section{FOOTNOTES}

1. This study was funded by the Indiana Commission on State Tax and Finance Policy. I wish to express my appreciation to Dr. Donald Kiefer, Director of that Commission, for comments on an earlier draft and for the comments of two anonymous referees. 
2. For a study considering only the benefit side of the grant-in-aid question, see: G. Ferman, "Output Analysis: The Distribution of Grants-In-Aid 1957-1967 A Preliminary Analysis," Working Paper No. 10, Center for the Study of Federalism, Temple University, Philadelphia, Penn., 1967.

3. An interesting discussion of the relationship between per capita income and grant-in-aid distribution is found in: M. A. Haskel, "Federal Grants and the Income-Density Effect," National Tax Journal, XV, (March, 1962), pp. 105-108. Haskel points out the need to consider not only the effect of income on grants but the interrelationship between income and population density. This interrelationship is considered and eliminated in the regression part of the study because multicollinearity limits the ability of regression analysis to accurately determine the importance of each of the interrelated variables.

4. Although as far as I can tell, urbanization has not explicitly been included as an explanatory variable in grant-in-aid distribution analysis, it has been an important variable in explaining State and Local expenditures. See, for instance, G. W. Fisher, "Interstate Variations in State and Local Government Expenditures," National Tax Journal, XVIII, (March, 1964), pp. 57-73 and S. Sacks and R. Harris, "The Determinates of State and Local Government Expenditures and Intergovernmental Flows of Funds," $\mathrm{Na}$ tional Tax Journal, XVIII, (March, 1964), pp. 75-85.

5. See, for instance, W. Z. Hirsch, Urban Economic Analysis, (New York: McGraw-Hill Book Company, 1973) p. 285, Table 9.2.

6. The idea for using unemployment rates as an explanatory variable came from an in-house study by the State off Indiana entitled "Analysis of Federal Grant-in-Aid Programs Received by the State of Indiana," Federal Funds and Fiscal Analysis Task Force, State of Indiana, State House, Indianapolis, Indiana, 1972.

7. G. Ferman, "Output Analysis: The Distribution of Grants-In-Aid 1957-1967, A Preliminary Analysis," Working Paper No. 10, Center for the Study of Federalism, Temple University, Philadelphia, Penn., 1967.

8. Sources of data used in this study are the following: $R_{i}$ - "Analysis of Federal Grant-in-Aid Programs Received by the State of Indiana," Federal Funds and Fiscal Analysis Task Force, State of Indiana, State House, Indianapolis, Indiana, 1972; $\mathbf{I}_{\mathbf{i}}, \mathrm{UN}_{\mathbf{i}}, \mathrm{P}_{\mathbf{i}}, \mathrm{E}_{\mathrm{ei}}, \mathrm{E}_{\text {wi }}, \mathrm{E}_{\text {hyi }}$, and $\mathrm{E}_{\text {wi }}$ - U.S. Department of Commerce, Statistical Abstract of the United States 1972 (Washington, D.C.: Government Printing Office, 1972), Tables 353 and 666, pp. 222 and 422-423; $\mathrm{E}$ hi and $\mathrm{E}$ pri - U.S. Department of Commerce, Government Finances 1970 (Washington, D.C.: Government Printing Office, 1970), Table 9, p. 33; URB li $_{\text {and }} \mathrm{URB}_{\mathbf{j}}$ - U.S. Department of Commerce, 1970 Census of Population Volume 1 (Washington, D.C.: Government Printing Office, 1970), pp. 1-71; the Federal part of each of the expenditure categories was obtained from the Department of the Treasury, Federal Aid to States, 1970 and 1971 (Washington, D.C.: Government Printing Office, 1970 and 1971).

9. The test for multicollinearity used in this study is that given by D. E. Farrar and R. R. Glauber, "Multicollinearity in Regression Analysis: The Problem Revisited," The Review of Economics and Statistics, XLIX, (February 1967), ,pp. 92-107. The multilinearity test is based on the partial correlation, r , between regressors $\mathrm{X}_{\mathrm{i}}$ and $\mathrm{X}$, other regressors held constant. Calculation of these partial correlation coefficients showed the correlation between urbanization and per capita income to be .71 and the correlation between urbanization and per capita welfare expenditures to be .96 . Both partial correlation coefficients were significantly different from zero at the one percent level of confidence.

10. The use of an auxiliary relationship to eliminate interrelationships between variables is based on work of R. G. Ridker and J. A. Henning, "The Determinates of Residential Property Values with Special Reference to Air Pollution, "Review of Economics and Statistics, 49, (June, 1967), pp. 246-256. The formal derivation of this technique can be derived from analysis presented in A. S. Goldberger, Econometric Theory, (New York: John Wiley 1964), pp. 194-197. I have changed the notation from that used by Ridker and Henning which is specific to their study.

11. This redistribution from relatively urbanized areas to less urbanized areas can readily be seen from several other regressions that were run using the numerator and denominator of $R_{i}$ as dependent variables. The regression coefficients for URB li are given bbelow.

Dependent
Variable

\section{Grants}

Grants

Tax burden

Tax burden

Grants per capita

Grants per capita

Tax burden per capita

Tax burden per capita

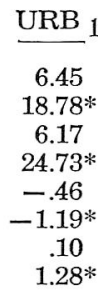

Other Regressors

variables equation $\left(2^{\prime}\right)$

variables equation $\left(2^{\prime \prime}\right)$

variables equation $\left(2^{\prime}\right)$

variables equation $\left(2^{\prime \prime}\right)$

variables equation $\left(2^{\prime}\right)$

variables equation ( $\left.2^{\prime \prime}\right)$

variables equation $\left(2^{\prime}\right)$

variables equation ( $\left.2^{\prime \prime}\right)$
$\mathrm{R}^{2}$

.32

.31

.42

.42

.74

.74

.97

.97

\section{*Significant at the .05 level of confidence}

Somewhat surprisingly our results show that while grant receipts increase as does URB li, per capita grant receipts decline as URB ${ }_{l i}$ increases. On a per capita basis individuals in relatively urbanized areas not only pay on the average more taxes into grant-in-aid programs but they also receive back on the average less federal aid thereby reinforcing the tax induced redistribution from urbanized to less urbanized states. 
12. See A. S. Goldberger, p. 197, op. cit.

13. Most of the debate on the use of Federal aid has taken place in various Indianapolis newspapers. See the following articles: "What it Costs," The Indianapolis News, 4/6/72, p. 14; "Welfare Bureaucracy Fought by Arizona," The Indianapolic News, 10/24/72, p. 20; "Good Idea," Editorial, The Indianapolis News, 6/22/73, p. 6; "Federal Aid to Hoosiers Ranks Last," Indianapolis Star, 6/20/73, p. 4; "Bowen is Sad Over Tax-Ratio," Indianapolis Star, 8/1/73, p. 1; "U.S. Grant Rules," Indianapolis News, 8/2/73, p. 1; "Cause to Weep," Editorial, Indianapolis News, 8/13/73, p. 14; "Nice Work If-," Indianapolis Star, 8/30/73, p. 28; "Indiana Last in Allocation of U.S. Funds Returned form Washington," Indianapolis Star, 9/19/73, p. 1. 